\title{
Using Stakeholder Engagement, Translational Science and Decision Support Tools for Ecosystem-Based Management in the Florida Everglades
}

\author{
Rebekah Gibble, Lori Miller, and Matthew C. Harwell
}

\begin{abstract}
Managing water for competing human and environmental demands in the Greater Everglades is a multi-dimensional challenge that includes managing a complex ecological system while providing water supply and flood control for widespread high-density urban communities and nationally important agricultural lands. Ecosystem-Based Management (EBM) in the Florida Everglades is examined at multiple spatial and temporal scales. There is a corresponding increase in the number and diversity of stakeholders involved as the temporal and spatial scales of management across the landscape increases. Therefore, translational science, decision support tools, effective stakeholder engagement, and communication are paramount. This chapter provides a case study of EBM in an aquatic system facing ecological challenges, such as eutrophication and non-indigenous species management, which are framed by complex social, cultural, and political contexts. A framework for navigating multi-agency governance models and competing stakeholder visions using socio-ecological science (i.e., science of interlinked human and natural systems) to address practical and theoretical challenges for managing freshwater wetlands is discussed. By examining best practices in stakeholder engagement and linking translational science with multiple, science-driven decision support tools, important lessons learned can be carried forward in an effort for continually improved governance and collaboration for ecosystem management and restoration.
\end{abstract}

\author{
R. Gibble $(\bowtie)$ \\ U.S. Fish and Wildlife Service, Boynton Beach, FL, USA \\ e-mail: rebekah_gibble@fws.gov \\ L. Miller \\ U.S. Fish and Wildlife Service, Vero Beach, FL, USA \\ e-mail: lori_miller@fws.gov \\ M. C. Harwell \\ U.S. Environmental Protection Agency, Gulf Breeze, FL, USA \\ e-mail: harwell.matthew@epa.gov
}




\section{Lessons Learned}

- Real-time monitoring data, frequently updated and accessible modeling output and stakeholder communication are key to successful EBM in complex socioecological systems, such as the Everglades.

- EBM recommendations should consider agency-specific missions and goals across the key stakeholders involved.

- Coordinating short, intermediate, and long-term recommendations at both local and regional scales may improve EBM outcomes.

- Incorporating real-time monitoring data from across the landscape, along information from model output, enhances EBM.

- Decision support tools that integrate monitoring data with spatial habitat and wildlife models enhance assessment of conditions and development of recommendations that support EBM.

\section{Needs to Advance EBM}

- Additional development of the decision-making process framework and further integration of decision support tools for use in multiple spatial and temporal scales.

- Increased/enhanced incorporation of EBM approach into existing governance models/mandates, and methods of communication of recommendations to managing agencies.

- Perhaps most importantly, increased connection of operational decisions to measuring the resulting ecosystem responses to support adaptive management will further enhance the success of the EBM approach in the Everglades.

\section{Introduction}

Wetlands are productive ecological systems that provide habitat to many species that form complex and interdependent communities. Wetland systems collect water and sediment from across the landscape and regulate hydrologic cycles that provide ecosystem services such as water filtration and supply, flood control, coastal protection from storms, carbon sequestration, natural products (e.g., shellfish), and recreational opportunities. Humans often alter these systems by draining them to provide fertile farmland or to support development. The hydromorphological alterations resulting from these socio-ecological interactions often lead to impacts such as decreased wildlife populations and reduced ecological service. However, when adaptively managed, wetlands can be sustainable and provide a range of ecosystem services to humans while providing crucial habitat to wetlands.

This chapter outlines key socio-ecological interactions across the landscape and the Ecosystem-Based Management (EBM) approach used to promote restoration of the natural function of the Everglades system while also providing numerous ecosystem services, such as water supply and flood control. This approach integrates 
stakeholder engagement with translational science and decision support tools to inform multipurpose water management operations. Communication between various groups (e.g., stakeholders, managers, etc.) is critical to the EBM process and, in the Everglades, is based on a framework comprised of formal and informal requirements. Throughout this chapter, the various components and linkages that make up the EBM approach in the Everglades are presented as a case study to illustrate the practical application of EBM across a landscape.

\section{Everglades Ecosystem}

\subsection{Overview of an Ecosystem in Trouble (Through 2000)}

The historical Everglades were $9307 \mathrm{~km}^{2}$ (2.3 million acres) of a vast wetland that began at a chain of lakes in the Kissimmee basin that flowed into Lake Okeechobee and stretched to the end of the Florida peninsula (Douglas 1947). Lake Okeechobee was historically $1891 \mathrm{~km}^{2}\left(730 \mathrm{mi}^{2}\right)$ in size and water depths fluctuated between 3-4 m (10-20 ft.) deep (McVoy et al. 2011). The lake acted as a natural reservoir storing water from the Kissimmee Chain of Lakes and during periods of high water from tropical cyclones. When full, the water spilled over into pond apple forests causing a wide swath of slow moving water in the form of sheetflow (Fig. 1) (McVoy et al. 2011). Water depths south of the lake in the sawgrass dominated Everglades ranged from 5-100 cm (2-40 inches) deep. The slow moving water with occasional periods of high pulse flows created a ridge and slough landscape that included tree islands as crucial habitat for wildlife and plant species. (Frederick and Ogden 2001). The slope of the land was so gradual at $5 \mathrm{~cm}$ per $1.5 \mathrm{~km}$ ( 2 inches per mile), that water only moved southward at $30 \mathrm{~m}$ (100 ft) per day (National Research Council 2010). This water eventually discharged into the mangroves of Florida Bay and the Ten Thousand Islands in southwestern Florida.

\subsection{Drying of the Marsh for Agriculture by Compartmentalization}

In the late 1800s through the 1930s, settlers sought to dry out the swamp south of Lake Okeechobee in order to use the rich muck and peat to grow crops. In 1947, major floods occurred over South Florida with over $2.5 \mathrm{~m}$ (100 in) of rain causing the United States Congress to authorize the Central and South Florida (C\&SF) Project in 1948, which was intended to provide drainage and flood control for the croplands and the outlying communities (Fig. 2) (Light and Dineen 1994). In spite of the public outcry against compartmentalization, $1600 \mathrm{~km}(100 \mathrm{mi})$ of levees, $1160 \mathrm{~km}(720 \mathrm{mi})$ of canals, and 200 water control structures (Light and Dineen 1994) were designed. 
Fig. 1 The historical and present Everglades. (Reproduced from the National Academies of Sciences, Engineering, and Medicine 2018)

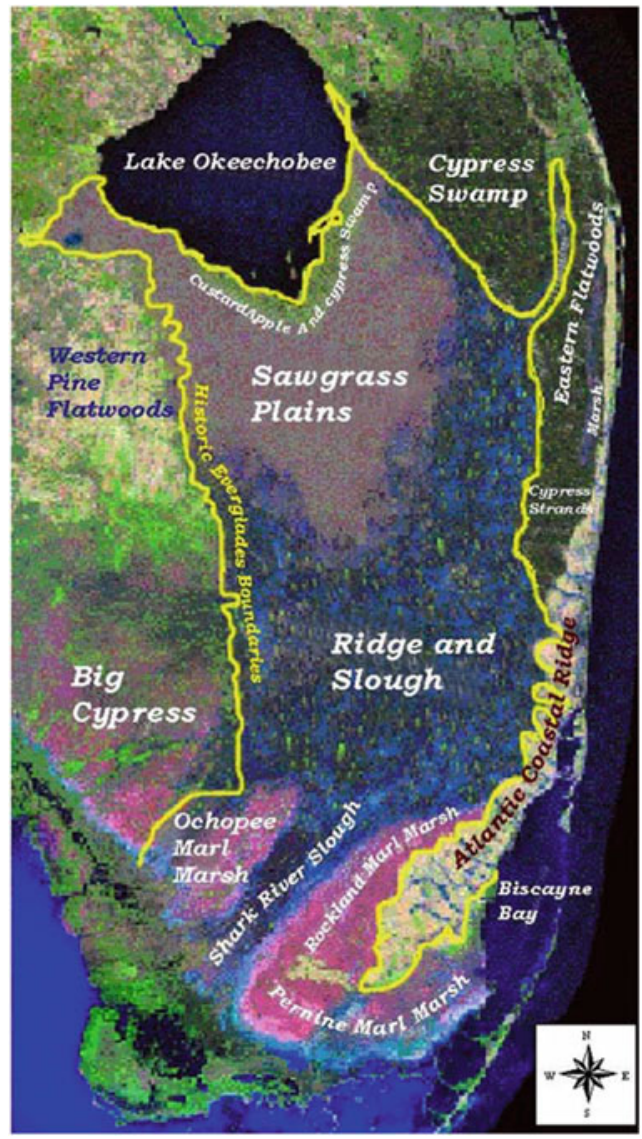

Although too late to stop damage to the Everglades, Marjory Stoneman Douglas published "The Everglades: River of Grass" in 1947 arguing for saving the Everglades.

The C\&SF project, built during the 1950s and 1960s, completely disconnected the historical Everglades. The historical sheetflow lost its natural headwaters and became a complicated water management system designed to provide flood control and continual drainage of the system for agriculture (National Research Council 2010). The drained area south of Lake Okeechobee became known as the Everglades Agricultural Area (EAA) and is approximately $2850 \mathrm{~km}^{2}\left(1100 \mathrm{mi}^{2}\right)($ Snyder and Davidson 1994). Multiple Water Conservation Areas (WCAs) covering approximately $3500 \mathrm{~km}^{2}\left(1350 \mathrm{mi}^{2}\right)$ were developed for managing water in the open areas of the Everglades.

The C\&SF Project had multiple direct, but adverse, hydrological impacts on the Everglades (US Department of the Interior 1994): 


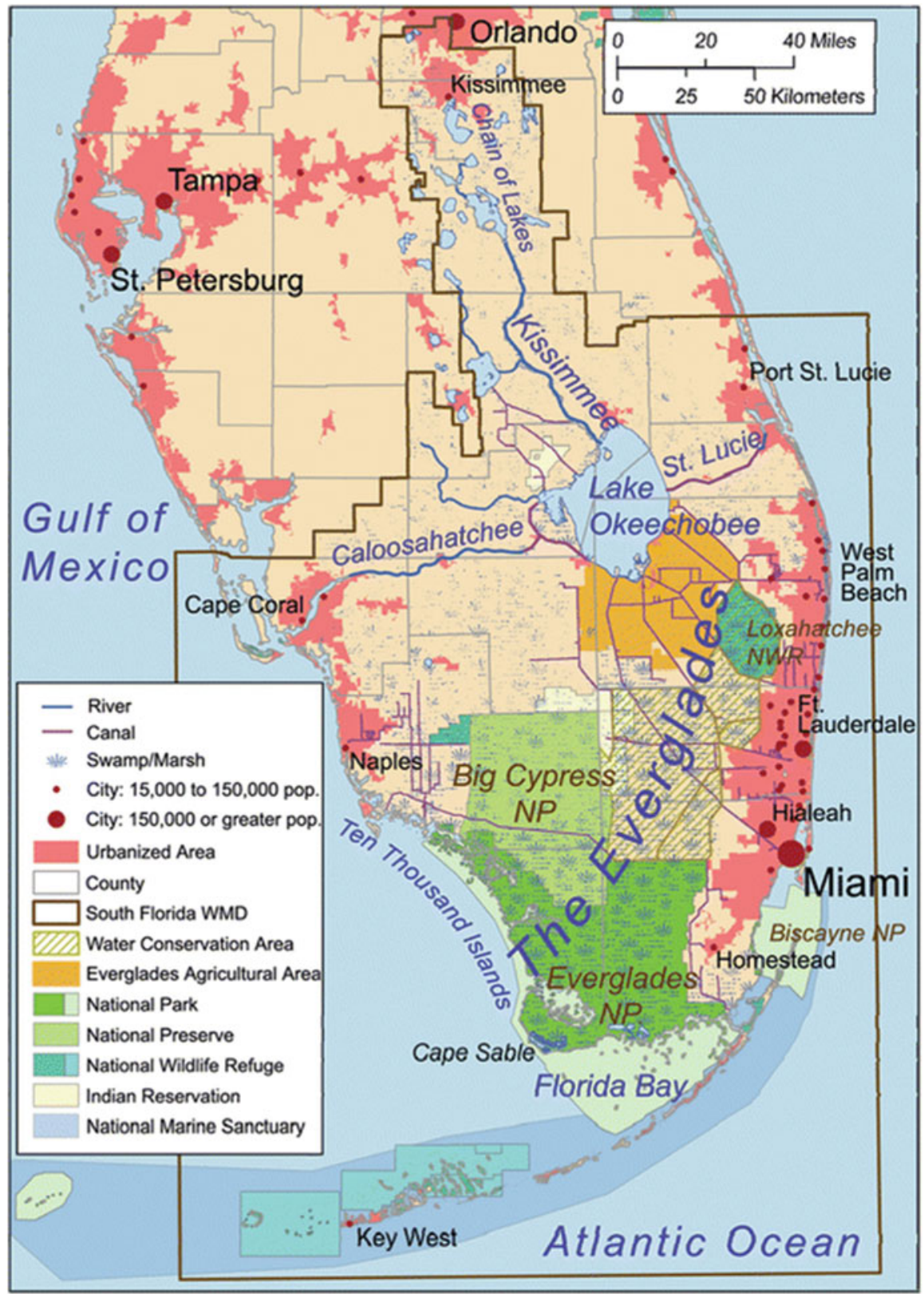

Fig. 2 C\&SF project compartmentalization of the Everglades into the Everglades Agricultural Area, Water Conservation Areas, preserves, and parks. (Reproduced from Musser 2010) 
- The Everglades were reduced in size by more than fifty percent $(50 \%)$ to approximately $4000 \mathrm{~km}^{2}$ (one million acres).

- Loss of an annual average of 2.7 billion $\mathrm{m}^{3}$ (2.2 million acre feet) of fresh water that flowed into the coastal estuaries along Florida's east and west coast due to lack of conveyance and storage to send the water south into the Everglades. The lack of sheetflow and the resulting altered hydroperiod in the remaining Everglades changed native vegetation and habitat.

- Lack of variability in water delivery drastically altered the seasonal patterns of high and low flows to the remaining Everglades.

- The Everglades continued losing its unique ridge and slough landscape, along with tree islands, causing a change in wildlife population abundances and distribution.

In the 1970s, the larger U.S. environmental movement brought more attention to the Everglades. By the late 1980s, state and Federal agencies, citizen groups, and the Tribes began focusing on restoring the Everglades ecosystem and protecting its species and habitats. Currently, there are 68 threatened and endangered species in the Everglades (USFWS 1999). The most noted species change has been in the population, distribution, and habits of wading birds native to the Everglades (Ogden 1994). Even the most basic component of the Everglades—water-is at risk. Water depths, duration, and overall distribution across the landscape changed with drainage, creating a suite of ecosystem changes (Kushlan 1987; Ogden 2005). Water quality has been consistently deteriorating due to agricultural chemicals, urban runoff, and animal waste from ranchlands and dairies upstream in the EAA, Kissimmee Chain of Lakes, and urban areas such as Orlando. Successful restoration of the Everglades ecosystem requires the appropriate interaction between the quantity, quality, timing, and distribution of water (ENP 2015).

\subsection{An Ecosystem Managed for Multiple Purposes (2000- Current)}

At present, the remaining greater Everglades ecosystem is a human-shaped environment that is managed for multiple purposes, including: flood protection, water supply, water flows for the environment, and habitat supporting a variety of flora and fauna. Water flow is a foundational element of most Everglades ecosystem management, with two primary water management agencies, the U.S. Army Corps of Engineers (USACE) and the South Florida Water Management District (SFWMD), making and implementing operational water management decisions. Smaller government entities and utilities, such as the Lake Worth Drainage District and the Everglades Drainage District, influence hydrology at smaller scales. Additionally, a mosaic of federal, State and Tribal lands exist throughout the greater Everglades Ecosystem Management decisions in these land units are made by the U.S. National Park System, U.S. Fish \& Wildlife Service, Florida Fish and Wildlife 
Commission, the Miccosukee Tribe of Indians of Florida, or the Seminole Tribe of Florida. Overall, the greater Everglades landscape is a complex, socio-ecological system involving a range of governance models (Ankersen and Hamann 1996). Each governing body is operated under a different suite of legal and policy mandates, with different levels and types of stakeholder engagement. Juxtaposed against this complex range of governance models is a large body of scientific research underscoring the interconnectedness of the landscapes and ecosystems. From this research, an increased understanding of the system has led to the development of a diverse array of tools to evaluate, assess, and predict system responses to management operations and restoration projects.

\section{Current Water Management}

The USACE monitors and manages the multi-purpose operations of spillways, locks, pump stations, culverts, canals, reservoirs, and water conservation areas (USACE 2019) and is considered a federal partner to the State of Florida's water management districts. Among other activities, such as water quality monitoring and scientific research, the SFWMD manages water supply, flood control, and is the State partner in Everglades Restoration. The SFWMD operates approximately 2100 miles of canals and 2000 miles of levees/berms, 77 pump stations and more than 600 water control structures and 620 project culverts across central and southern Florida (SFWMD 2019). This extensive network of infrastructure (Fig. 3) encompasses three water conservation areas (WCAs), large wetland areas that are compartmentalized by berms and levees and receive and discharge water through water control structures. The WCAs make up the Greater Everglades and are located upstream of Everglades National Park (ENP). Historically, the Everglades were compartmentalized into WCAs to prevent catastrophic flooding as witnessed before the C\&SF project was authorized in 1948. The WCAs store rainfall, Lake Okeechobee flood releases, and excess water runoff from the EAA, as well as recharge aquifers, reduce seepage into urban areas, and protect against salt water intrusion from rising sea levels. The WCAs also provide flow-through capacity of water cleaned (primarily by removal of phosphorus) by stormwater treatment areas (STAs). STAs are constructed wetlands that remove and store nutrients through plant growth and the accumulation of dead plant material. STAs are comprised of parcels of land utilizing different types of emergent (e.g., cattails, pickerel weed and bulrush) and submerged (e.g., hydrilla, southern naiad and chara) plants that take phosphorus directly from the water in STAs (SFWMD 2019). STAs are critical for providing environmental benefits to the Everglades landscape, species, and their habitats. (USGS 2013). 


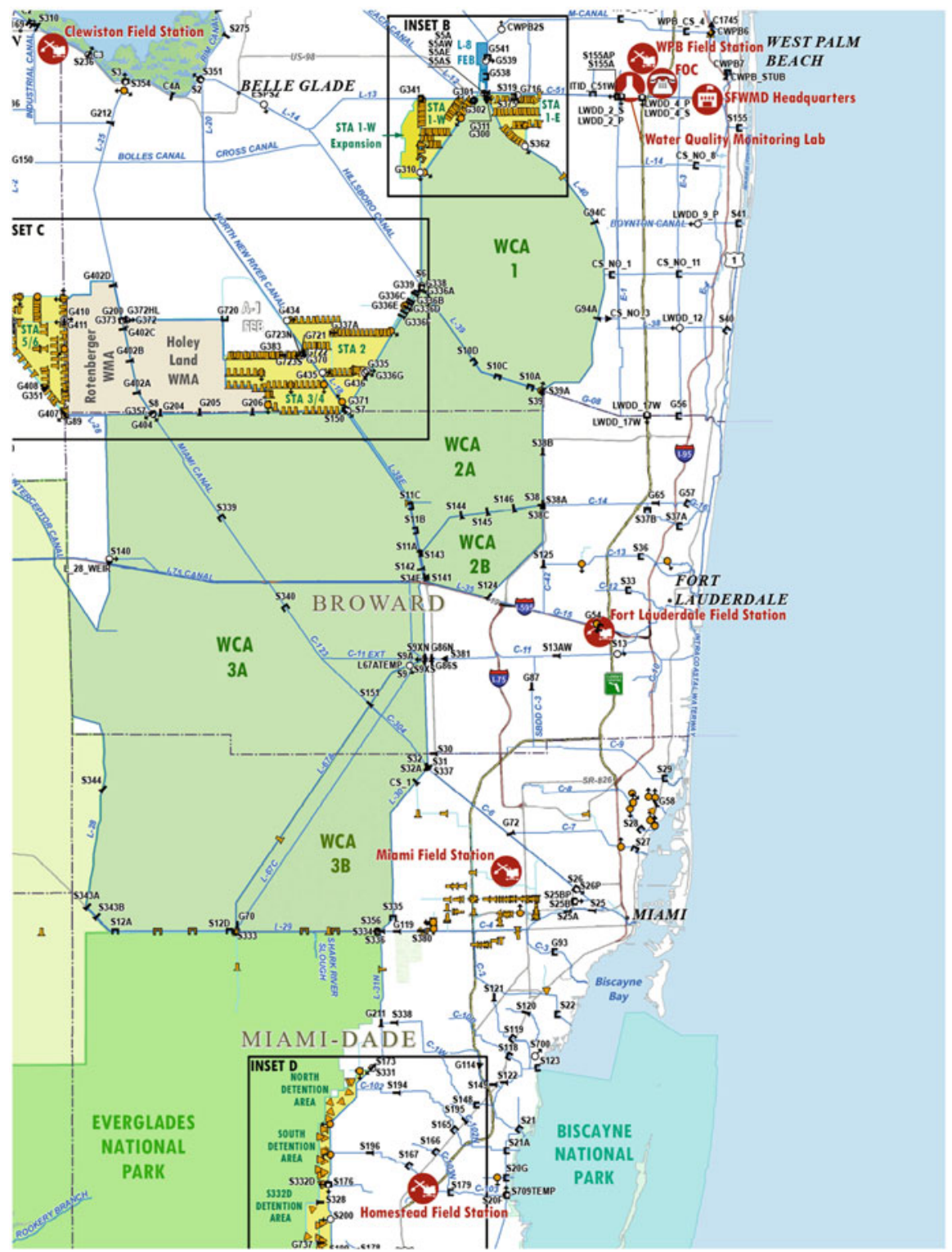

Fig. 3 Facility and infrastructure location index map indicating canals, pumps, weirs, spillways, and stormwater treatment areas in yellow. (Reproduced from SFWMD 2016) 


\subsection{Rainfall, Regulation Schedules, and an Altered Ecosystem}

Rainfall drives the hydrology of the Everglades. However, water management actions also influence hydrologic conditions throughout the ecosystem. Lake Okeechobee and the WCAs are managed by Water Regulation Schedules, which are a set of rules based on antecedent conditions, rainfall formulas, monthly and seasonal rainfall based water management plans, and regulatory requirements for flows into ENP. Regulation schedules (e.g., Fig. 4) provide recommended operational guidelines for maintaining target water level ranges in each WCA, which are monitored through a complex network of gauges. They also provide recommended water levels for the beginning of the dry season (November 1) and for the beginning of the wet season (June 1). Water managers can implement operational changes that deviate from a regulation schedule during and after an extreme rainfall event. This "deviation" can exceed normally recommended water discharges to get water levels lowered more quickly to acceptable levels.

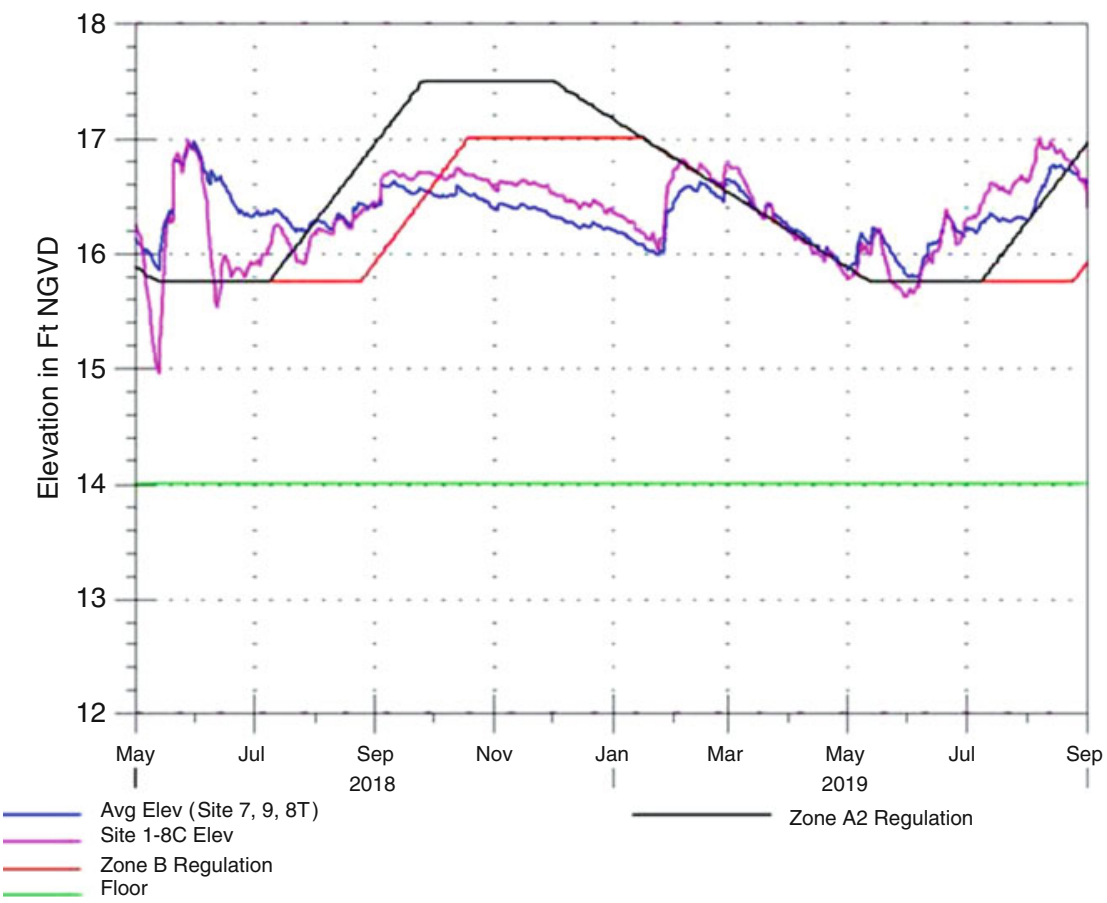

Fig. 4 Regulation schedule and water levels in 2018 for Water Conservation Area 1 within the Greater Everglades. Red and black lines indicate surface water elevation targets throughout the year. Purple and blue lines indicate actual surface water elevations resulting from water management operations and rainfall in Water Conservation Area 1 (USACE 2019) 
At times, water management rules can be in conflict with the environmental needs of species and their habitats, although the intent of Everglades restoration projects is to mimic the natural hydrology of the Everglades. Hydrologic and ecological studies have shown that some rules could be altered to better mimic the Everglades' natural hydrology. This has been particularly evident with some of the State and federally listed threatened and endangered species (e.g., Snail Kites (Rostrhamus sociabilis plumbeus), Wood Storks (Mycteria americana), wading birds, and Cape Sable Seaside Sparrows (Ammodramus maritimus mirabilis) (USFWS 2016). Some of the habitat these species depend upon has become altered due to unnatural water depths, shorter- or longer-than usual hydroperiods, and altered rates and patterns of flow. The succession of short-hydroperiod marl prairie grasses to long-hydroperiod sawgrass in naturally occurring high ground in ENP is a prime example of areas becoming unnaturally wet due to water management operations. Management operations of water levels in the Kissimmee Chain of Lakes, Lake Okeechobee, and the Kissimmee River have also led to the deterioration of Snail Kite habitat in lake littoral zones and river floodplains (Cattau et al. 2008). Snail Kites breed and nest in the littoral zones and floodplains, which are also home to their primary prey, the apple snail. It has been documented that water management operations have at times reduced water levels too rapidly, causing damage to the habitat and forcing the apple snail to move into deeper water and leaving apple snail egg clusters without necessary water levels to survive (Bennetts and Kitchens 1997). For Wood Storks and wading bird colonies, $41 \mathrm{~cm}$ (16 in) of water depth is required to support their fish prey. Water management operations can, and have, either flooded or quickly dried out, core foraging areas for wading birds (USFWS 2014).

Because of the potential negative effects to listed threatened and endangered species, water management in central and southern Florida has occasionally been changed and amended by federal regulatory documents, such as a USFWS Biological Opinion (BO). A recent BO mandated that water managers coordinate with ecologists and biologists from state and federal government agencies, non-governmental organizations, and other interested parties prior to changing particular structural operations due to potential upstream or downstream ecological effects. These BOs are also responsible for changing the rate and timing of structural flows to better mimic natural rainfall and hydrology to protect certain habitats like the marl prairie in ENP (USFWS 2016). However, it was recognized in the 1999, and all subsequent BOs, that there would be times when unseasonal rainfall could and will overwhelm the water management system. During those times, it is critical to "share adversity" among stakeholders and thus, closely coordinate among agencies to provide the best operations for human health and safety, the Everglades landscape, and the biology and ecology of the system (USFWS 2016). 


\subsection{Monitoring and Current Status of the Ecosystem}

Changes in hydrology (hydromorphological alterations), water quality, and water management are the principal stressors that affect the ecosystem (e.g., Walker 1999). Monitoring hydrology includes maintenance of hydrologic monitoring gauges, collection of data, and processing and dissemination of hydrologic data. The monitoring station network (Fig. 5) within the ecosystem is comprised of almost 300 gauges (USGS 2009) that measure water stages and water quality and are operated by the Big Cypress National Preserve (BCNP), ENP, SFWMD and United States Geological Survey (USGS) (2009).

These gauges are used to model surface water elevations and depths across the landscape, often as related to wildlife, (e.g., Fig. 6), and can be used for planning purposes. New gauges may occasionally be needed in strategic areas due to topographic variability. However, the need for new gauges is weighed against habitat impacts resulting from installation (USFWS 2016).

\subsection{Planning for Future Water Management Operations}

As a federal partner, USACE water managers monitor gauges, water depths, and regulation schedules of water conservation areas. These activities include analyzing past and predicted rainfall events and considering the requirements of a multitude of stakeholders, including, but not limited to, navigation, ecological needs, agriculture, and recreation. The SFWMD uses risk analysis to evaluate the "present condition" of the system, on which to base its water operations recommendations. The purpose of the risk assessment is to evaluate water resources and the risks associated with operational decisions (Hirsch 1978). This evaluation is accomplished by estimating the probability distribution function of select variables, conditional on the current, or otherwise specified, state of the system (SFWMD 2019). The SFWMD also provides historical rainfall on a monthly and seasonal basis. Other agencies provide products and input to operational planning including the Climate Prediction Center (CPC) with rainfall predictions out to a year, the National Weather Service (NWS) with quantitative precipitation forecasts out to seven days, USGS and ENP with EDEN (Everglades Depth Estimation Network) ecosystem-wide water depths, and USFWS with the Species Climate Outlook that focuses on the expected climate out to 12 months, but includes general weather expectations for species across the State, projected out to 2100. Each source of data, including model projections, provides value added information to the larger discussion that was not systematically incorporated into the historical discussion on how to best manage water operations. 


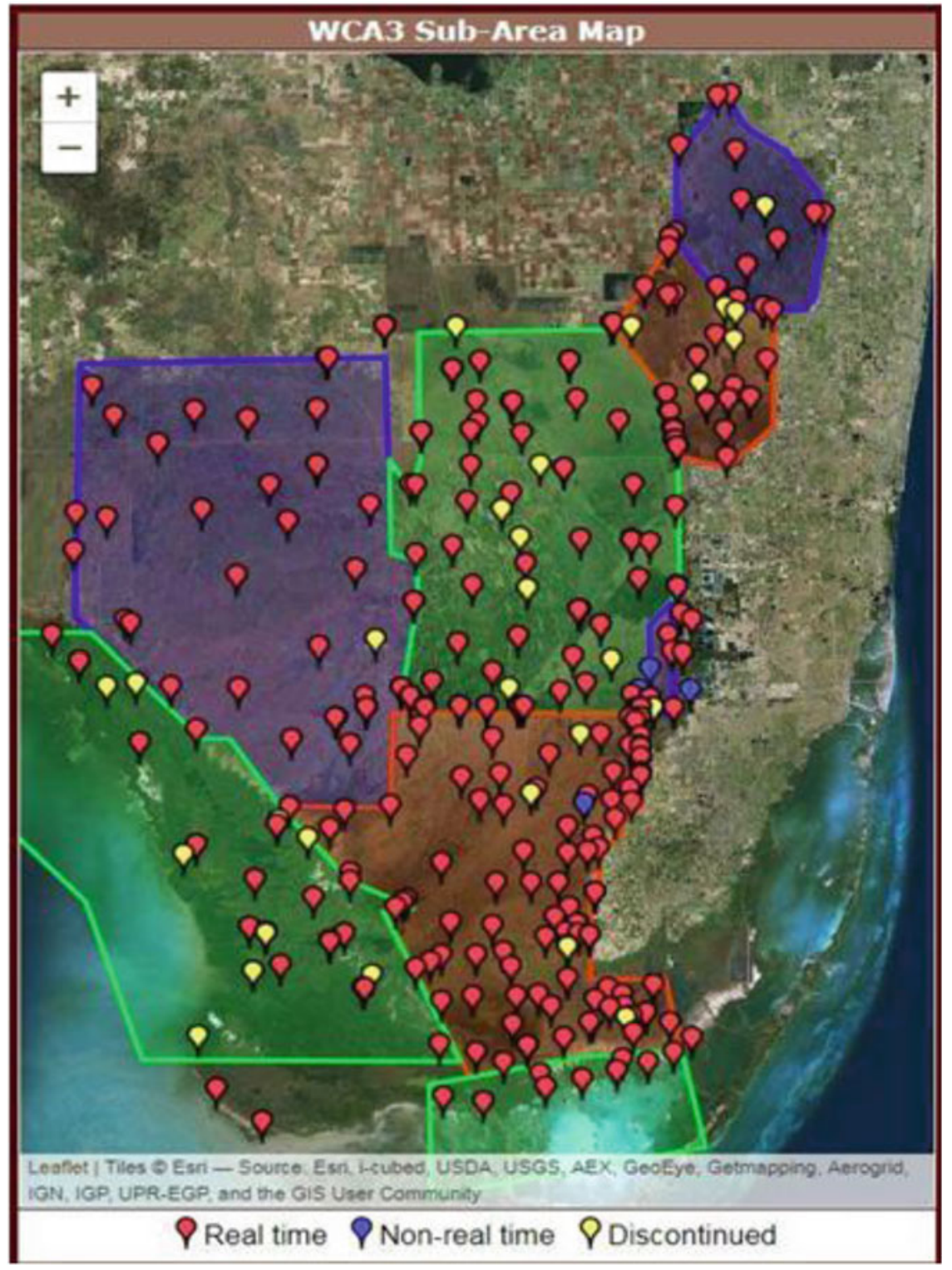

Fig. 5 Gauge locations for monitoring water levels and water quality in the Everglades. (Reproduced from USGS 2009) 


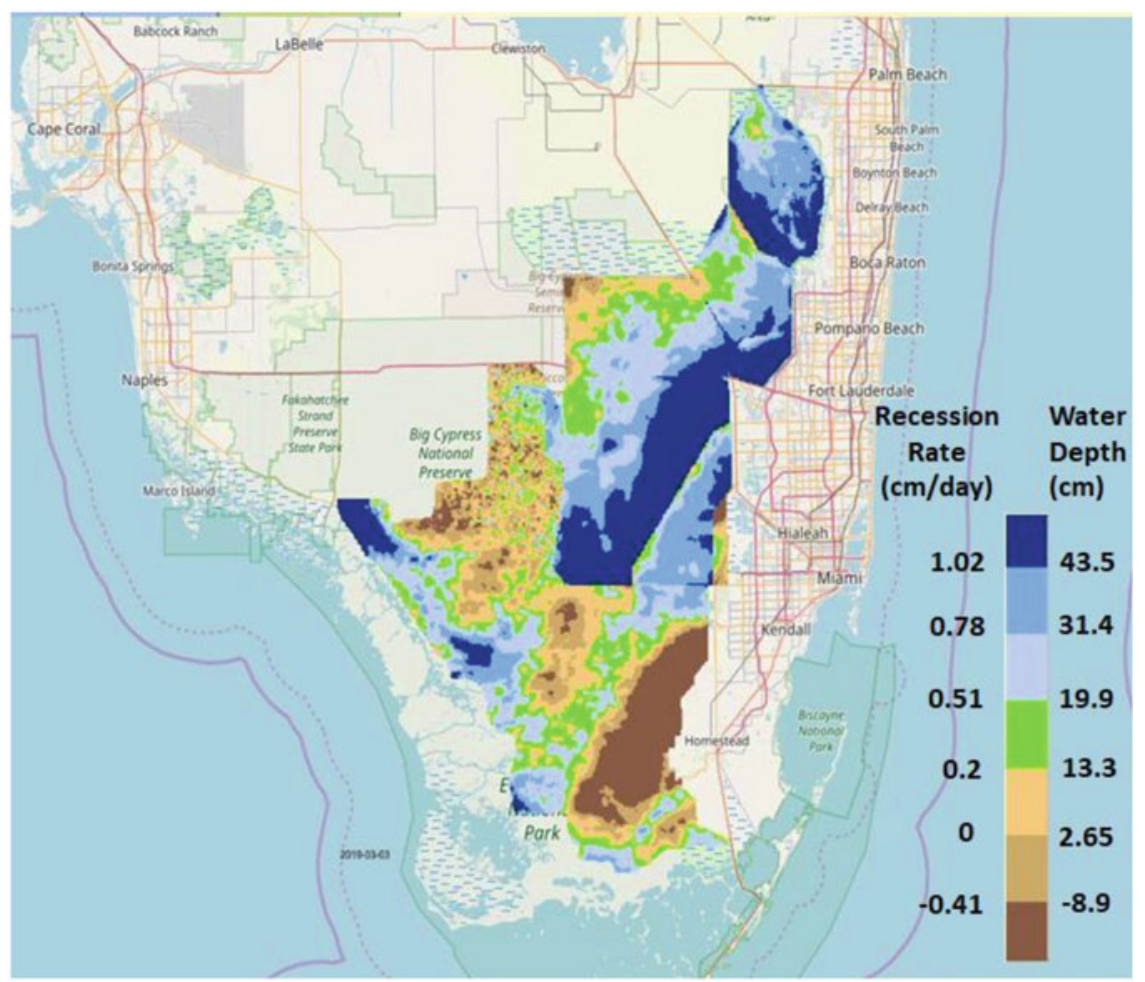

Fig. 6 Example of a water depth map, taken from the Wading Bird Depth Viewer. (Reproduced from USGS 2009; https://sofia.usgs.gov/eden/wadem/)

\section{Translational Science}

Translational science focuses on the importance of communicating scientific information to "connect end-users of environmental science to the field research carried out by scientists" (Schlesinger 2010). The use of a strategic communication approach (Harwell et al. 2020) thus can be useful in efforts to achieve effective EBM based on the EBM principle that, "decisions reflect societal choice" (Long et al. 2015). While "strategic communication" approaches were not explicitly identified in many EBM examples, a large EBM case study analysis by Mattheiß et al. (2018) concluded that "the better the communication strategy the likelier the demand for scientific knowledge from the social system." The translation of science within the context of ecosystem management is key to a broad understanding of both social and ecological systems and their interlinkages, which promote the development of innovative tools and management approaches to sustain biodiversity and the longterm delivery of ecosystem services (Piet et al. 2017).

As a complex socio-ecological system, the Greater Everglades involved numerous stakeholders from backgrounds including government agencies, universities, 
USFWS Multi-Species Transition Strategy for WCA-3A

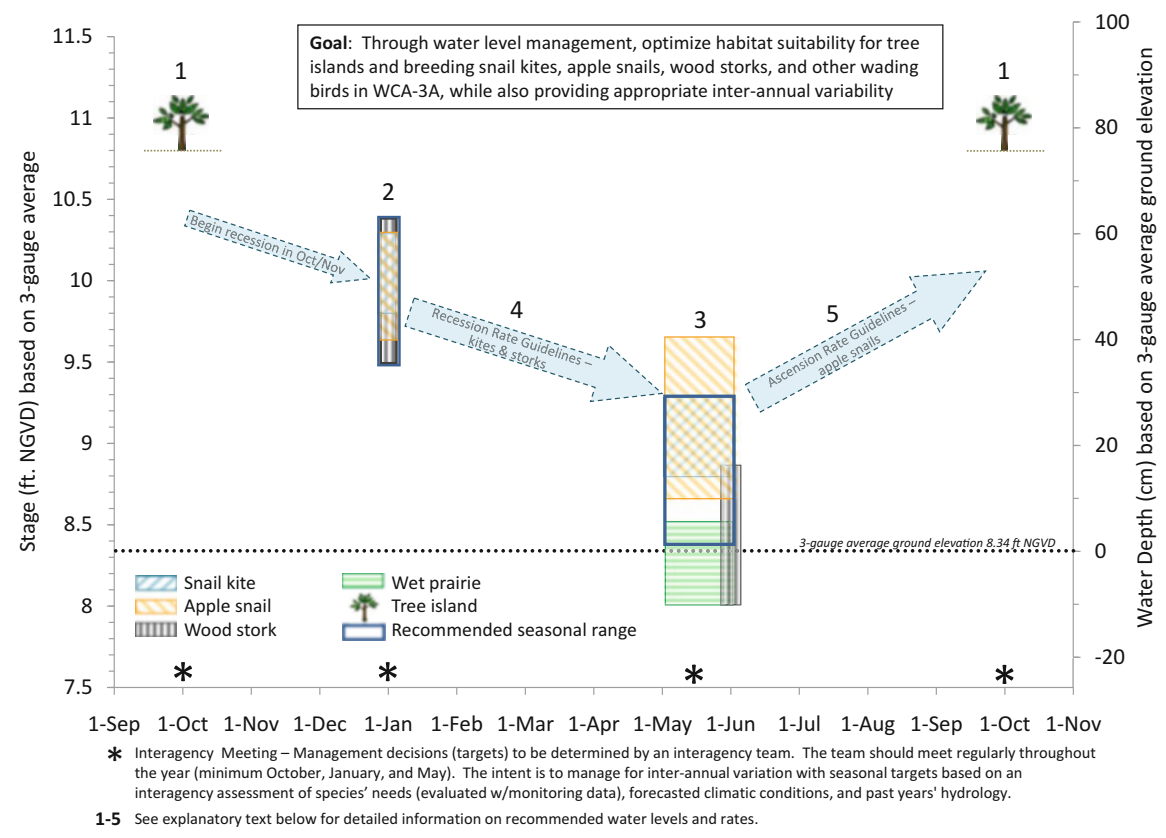

Fig. 7 USFWS Multi-Species Transition Strategy for Water Conservation Area 3A. Strategy includes recommending ranges and targets for species and habitats likely to be impacted by Everglades Restoration projects. *Denotes timing of intended interagency coordination meeting. (Reproduced from USFWS 2010)

non-profit conservation organizations, and tribes that rely on receiving ecosystem services. A variety of managing local, state, and federal agencies provide those services through ecosystem management of the adjoining Everglades. These same agencies, plus universities and other organizations, conduct research, collect monitoring data, and fill key roles in water management decisions and operations. Due to this complexity, communication among stakeholders that can be impacted by water management decisions, managers that make operational decisions and scientists collecting research and monitoring data is central to effectively applying EBM to an ecological system, particularly at the landscape scale. For the purposes of EBM of the Everglades, the need to strategically communicate the elements of translational science (e.g., Harwell et al., 2020) have been acknowledged for decades for both ecosystem management (Kushlan 1979) and ecosystem restoration purposes (Harwell 1997). Here, a translational science framework for EBM in the Everglades (Fig. 7), involves the communication of information among scientists, water managers, and stakeholders. Much of this EBM framework is foundationally defined in regulatory and/or planning documents related to Everglades Restoration (e.g., Biological Assessments under the Endangered Species Act (ESA), Environmental Impact Statements under the National Environmental Protection Act) and implemented at a high level through related programs such as the Restoration 
Coordination and Verification (RECOVER) and the Congressionally mandated South Florida Ecosystem Restoration Task Force, as well as through field-level coordination between scientists and land managers. As such, these stakeholders helped define and develop the operational EBM framework presented here. We do recognize that other EBM frameworks have been developed for larger spatial and/or governance scales, such as the AQUACROSS framework (Piet et al. 2017).

At a field level, science generated by agency scientists (both associated with the operational management of the system and other agencies' supporting science) is translated into status and condition information for both ecosystem components (e.g., wading birds, tree islands) and the underlying hydrology and environmental conditions. This information is fed to stakeholders, including water managers and operational decision makers through a suite of communication forums (e.g., weekly and quarterly coordination meetings) and media (e.g., model output, informational graphics, narrative and numerical assessment statements). Water managers and operational decision makers translate this information into the context of agency mandates, goals, and operational constraints to make decisions that change the water management of the system. The resulting ecological outcomes, part of the monitoring effort for determining success, is folded back into the status and condition information as part of a larger adaptive management cycle. While water management decisions are still made by sector-focused operational managers, the Everglades EMB framework creates both the mechanism and the opportunity for other Everglades socio-ecological system goals and information to be served up for consideration.

This framework allows for real-time integration of operations data from discrete structures, knowledge of hydrodynamics throughout the system, modeled surface water elevations, and information on ecological envelopes (e.g., boundary conditions) for various species to develop water management recommendations for the best ecological outcome on multiple temporal and spatial scales. Recommendations are made with other uses, constraints, and regulations in mind but focus on ecological outcomes by aiming to identify where the system could use more/less water or; faster/slower water level ascension/recession rates, as well as highlight ecologically sensitive areas and/or species and habitats for a given operational decision.

\section{Managing Eco-hydrology in the Everglades}

Species typically used as indicators of Everglades ecosystem health and restoration success represent a range of habitats, behavioral characteristics, niches, and conservation status (Doren et al. 2009). Different species are used as indicators at different scales depending upon their response time to changes in environmental conditions, data availability, and the utility of relevant tools (Doren et al. 2009). Common indicator species include alligators, wading birds, Snail Kites, and apple snails. Typical habitats, such as tree islands, sawgrass ridges, and sloughs provide the basic structure of the Everglades and are sensitive to changes in water management. 
All wildlife and habitats in the Everglades are adapted to annual patterns of rainfall and regional flooding. Typical Everglades habitats are characterized by a range of conditions largely driven by water levels and hydroperiods, which vary widely throughout the system because of a north-south elevation gradient, variations in landscape micro-topography that drive water levels and hydroperiods, and seasonal rainfall patterns that result in a typical dry season (November-April) and wet season (May-October).

Species that have evolved with the Everglades are able to survive in the highly dynamic system characterized by low nutrients and extremely variable intra- and inter-annual water levels using a variety of strategies, such as synchronization of breeding seasons with periods of suitable water levels and prey availability. In general, wading birds are colonial nesters and under typical conditions largely use the same flooded areas for nesting from year to year. Some species, such as Wood Storks, travel long distances to forage if conditions in their typical nesting spots are not ideal. However, other species, such as the non-wading Snail Kite, are more nomadic and select annual nesting sites based upon where conditions in the system are most conducive to successful nesting (i.e., appropriate nesting materials available and water levels that are 20-80 cm (50-200 in.) deep (Bennetts et al. 1988). These water depths protect nests from land-based predators and provide suitable habitat for their primary prey, apple snails, which prefer depths less than $50 \mathrm{~cm}$ (125 in.) (Darby et al. 2002). Species such as the endangered Cape Sable Seaside Sparrow nest near the ground yet require dry habitat to breed, and are therefore dependent upon areas of higher elevation with shorter hydroperiods. This diversity in habitat requirements are largely provided throughout the Everglades ecosystem by changes in ground surface elevation and extensive micro-topography, which results in a mosaic of habitats encompassing a range of water depths and hydroperiods across the landscape.

The Everglades ecosystem is heavily impacted by socio-ecological pressures, such as efforts to provide flood control and water supply to surrounding urban and agricultural development. Water managers strive to operate existing water control structures across the landscape in a coordinated fashion with the overall goal of providing conditions similar to those historically driven by rainfall and natural sheetflow, while providing crucial ecological services such as flood control and urban/agricultural water supply. Creating natural conditions in this highly impacted and managed system requires the complex integration of operational constraints, regulations, and policies, with the varied habitat requirements and population status of the suite of indicator species. For example, tree islands and ridge and slough habitat types, as well as the underlying peat substrate, are sensitive to hydrologic patterns such as water depth and hydroperiod. Science-based thresholds for water depths and hydroperiods are used to inform recommendations so that management is protective of these habitat features.

Because of the inextricable link between wildlife and water in the Everglades, consideration of past, current and future water conditions, habitat conditions, and wildlife population status at short, mid- and long-temporal scales are crucial for making water management recommendations that are protective of sensitive wildlife and habitats. The earliest formalized effort to summarize and integrate suitable 


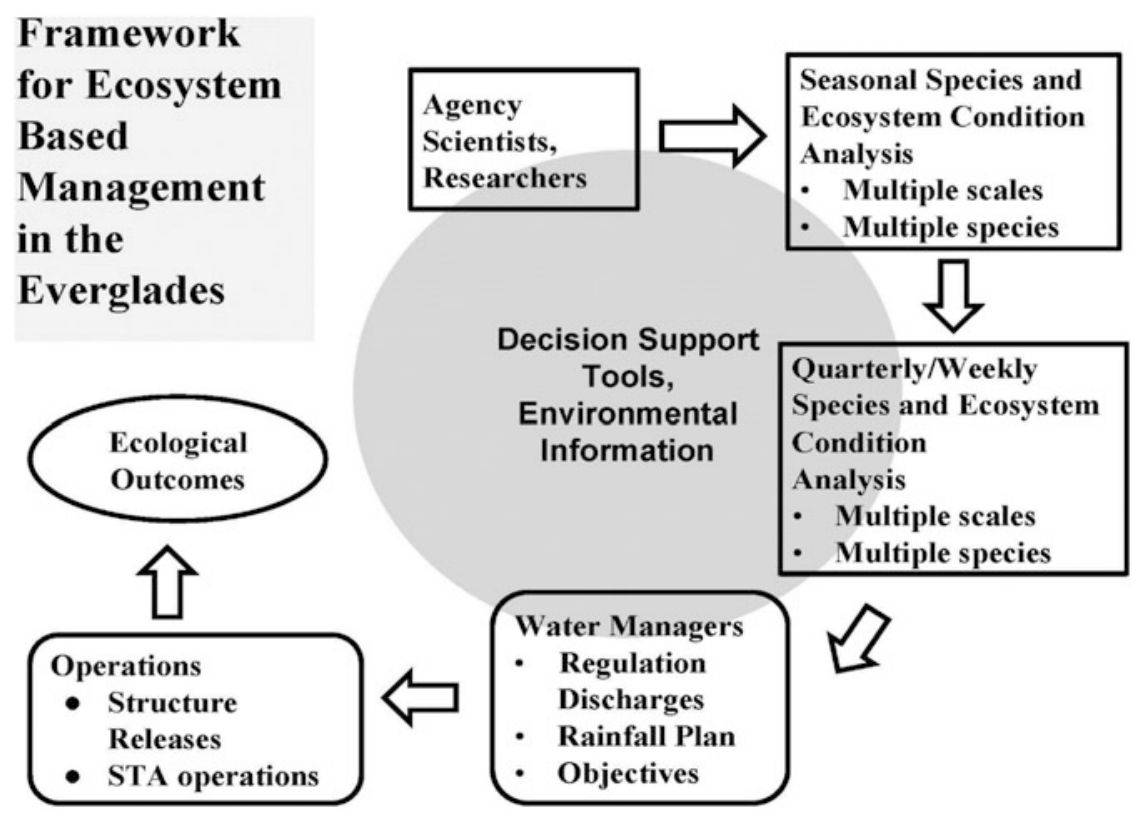

Fig. 8 Framework for Ecosystem-Based Management in the Greater Everglades ecosystem. Decision support tools and environmental information (shaded circle in background) provide an overarching anchor for EBM

conditions for a range of species was the Multi-Species Transition Strategy (MSTS) for WCA-3A in the Everglades Restoration Transition Plan (ERTP) developed by the Ecological Services branch of the USFWS as part of ESA Section 7 consultation (Fig. 8) (USFWS 2010).

The MSTS plan includes descriptions of the typical hydrologic ranges and timing of suitable conditions for multiple species considered indicators of Everglades Restoration. The plan, available to inform operations, management, and restoration decisions, directly compares and illustrates tolerance ranges for different sensitive habitat types and species, allowing identification of overlapping conditions and potential conflicts for management of these species. The information in this plan is combined with current, past, and projected future habitat conditions to inform daily/ monthly/seasonal ecological recommendations for water management, with a particular focus on areas impacted by ongoing restoration construction projects by the USACE.

The ability to develop effective recommendations is dependent upon accurate, real-time data regarding habitat conditions and the ability to predict the likely response of wildlife populations to management operations. Much of the available research and/or monitoring efforts are driven by a given species' conservation status, population status, and/or inclusion in USFWS' species recovery plans, the Monitoring and Assessment Plan (RECOVER 2009), and indicator species identified by the 
Department of Interior's South Florida Ecosystem Restoration Task Force, which is part of the Comprehensive Everglades Restoration Plan (CERP) (USACE and SFWMD 1999). Species designated with official conservation status, such as species protected by the ESA, or designated as a Florida Species of Special Concern, may have additional regulatory or recommended guidelines available to incorporate into a decision-making framework.

There are a variety of available tools and reports for determining and assessing antecedent, current, and potential future conditions such as USGS' EDEN, a landscape-scale surface water depth model, the National Oceanographic and Atmospheric Administration (NOAA) long- and short-term climate outlook predictions (Quantitative Precipitation Forecasts; QPFs), past rainfall trends, and the USFWS' Species Climate Outlook report, which characterizes forecasted conditions based on the requirements and tolerances of select species. A suite of scientists from universities, local, State, and federal agencies, Tribes, private consultants, and non-profit organizations provide wildlife population status and habitat requirement updates from ongoing research and monitoring efforts.

In addition to driving research and enabling partnerships, the CERP provides a critical framework for incorporating science, including new research and monitoring data, into management decisions using an adaptive management strategy (Loschiavo et al. 2013) creating opportunity for applying Ecosystem-Based Management (EBM) approaches to achieve restoration goals. A significant amount of resources have been invested in using results from scientific investigations to develop additional decision support tools to inform water operations and habitat management across the entire Everglades landscape (Table 1). These tools combine routinely collected environmental data with wildlife data and habitat condition information that can be used to assess past, current, and likely future conditions across the landscape to predict and evaluate potential impacts/benefits of water management and operations to wildlife and habitats.

Government and university partners developed the most easily accessible and frequently updated spatial modeling tools. These tools are used for making daily, weekly, and seasonal ecological recommendations. Many tools include maps that integrate known habitat preferences of a suite of wading birds, including the federally threatened Wood Stork (e.g., preferred water depths, rate and direction of change in water levels) with current and/or future conditions to indicate different levels of habitat suitability across the Everglades landscape (Wading Bird Depth Viewer, WADEM; Table 1). A similar tool based on recommended hydroperiod and water depths is available for the federally endangered Cape Sable Seaside Sparrow (Sparrow Viewer; Table 1), as well as other species such as Snail Kites and apple snails. While these tools and species updates are available to be individually considered by water managers when making operational decisions, most available tools do not provide a high-level integration of information or provide specific ecological recommendations. 
Table 1 Names, descriptions, and sources of some of the spatial modeling tools used to develop multispecies water management recommendations in the Everglades

\begin{tabular}{|c|c|c|c|c|}
\hline Species & Status & $\begin{array}{l}\text { Time- } \\
\text { scale }\end{array}$ & $\begin{array}{l}\text { Tool } \\
\text { description }\end{array}$ & $\begin{array}{l}\text { Translational science information } \\
\text { and source }\end{array}$ \\
\hline $\begin{array}{l}\text { Snail } \\
\text { Kites }^{\mathrm{a}}\end{array}$ & $\begin{array}{l}\text { Federally } \\
\text { Endangered }\end{array}$ & $\begin{array}{l}\text { Real- } \\
\text { time; } \\
\text { Long- } \\
\text { term }\end{array}$ & EVERKite & $\begin{array}{l}\text { Generates spatial maps of condi- } \\
\text { tions for Snail Kites, either current } \\
\text { or simulated under different hydro- } \\
\text { logic scenarios; specifically refers } \\
\text { to targets defined in USFWS Bio- } \\
\text { logical Opinion. https://www.jem. } \\
\text { gov/Modeling/EverKite }\end{array}$ \\
\hline $\begin{array}{l}\text { Apple } \\
\text { Snails }^{\mathrm{a}}\end{array}$ & $\begin{array}{l}\text { Least Concern; Pri- } \\
\text { mary prey of } \\
\text { endangered Snail } \\
\text { Kite }\end{array}$ & $\begin{array}{l}\text { Long- } \\
\text { term }\end{array}$ & EVERSnail & $\begin{array}{l}\text { Generates estimated population } \\
\text { size under different hydrologic } \\
\text { scenarios. https://www.jem.gov/ } \\
\text { Modeling/AppleSnail }\end{array}$ \\
\hline $\begin{array}{l}\text { Wood } \\
\text { Storks }\end{array}$ & $\begin{array}{l}\text { Federally } \\
\text { Threatened }\end{array}$ & $\begin{array}{l}\text { Real- } \\
\text { time; } \\
\text { Long- } \\
\text { term }\end{array}$ & WADEM & $\begin{array}{l}\text { Generates spatial maps of condi- } \\
\text { tions for wading birds, including } \\
\text { Wood Storks, either current or } \\
\text { simulated under different hydro- } \\
\text { logic scenarios; specifically refers } \\
\text { to targets defined in USFWS Bio- } \\
\text { logical Opinion. https://www.jem. } \\
\text { gov/Modeling/WADEM }\end{array}$ \\
\hline $\begin{array}{l}\text { Wading } \\
\text { Birds }\end{array}$ & Varied & $\begin{array}{l}\text { Real- } \\
\text { time; } \\
\text { Long- } \\
\text { term }\end{array}$ & WADEM & $\begin{array}{l}\text { Generates spatial maps of condi- } \\
\text { tions for wading birds, including } \\
\text { Wood Storks, either current or } \\
\text { simulated under different hydro- } \\
\text { logic scenarios; specifically refers } \\
\text { to targets defined in USFWS Bio- } \\
\text { logical Opinion. https://www.jem. } \\
\text { gov/Modeling/WADEM }\end{array}$ \\
\hline Alligators ${ }^{\mathrm{b}}$ & $\begin{array}{l}\text { Threatened due to } \\
\text { similarity of } \\
\text { appearance } \\
\text { (USFWS) }\end{array}$ & $\begin{array}{l}\text { Long- } \\
\text { term }\end{array}$ & $\begin{array}{l}\text { Alligator } \\
\text { Model }\end{array}$ & $\begin{array}{l}\text { Generates spatial distribution maps } \\
\text { of environmental condition related } \\
\text { to Habitat, Breeding, Courtship \& } \\
\text { Mating, Nest Building, Nest } \\
\text { Flooding, Overall Suitability, either } \\
\text { current or simulated under different } \\
\text { hydrologic scenarios. https://www. } \\
\text { jem.gov/Modeling/Alligator }\end{array}$ \\
\hline $\begin{array}{l}\text { Cape } \\
\text { Sable Sea- } \\
\text { side } \\
\text { Sparrow }^{\mathrm{a}}\end{array}$ & $\begin{array}{l}\text { Federally } \\
\text { endangered }\end{array}$ & $\begin{array}{l}\text { Real- } \\
\text { time; } \\
\text { Long- } \\
\text { term }\end{array}$ & $\begin{array}{l}\text { Sparrow } \\
\text { Viewer }\end{array}$ & $\begin{array}{l}\text { Generates maps of current or sim- } \\
\text { ulated conditions as related to Cape } \\
\text { Sable Seaside Sparrow; either cur- } \\
\text { rent or simulated under different } \\
\text { hydrologic scenarios; specifically } \\
\text { refers to targets defined in USFWS } \\
\text { Biological Opinion. https://sofia. } \\
\text { usgs.gov/eden/csss/index.php }\end{array}$ \\
\hline
\end{tabular}

For more on translational science aspects, the reader is directed to Sect. 4

${ }^{a}$ USFWS Multi-Species Recovery Plan (USFWS 1999)

b2009 Revised CERP Monitoring and Assessment Plan (RECOVER 2009) 


\section{Integrating Information Into Recommendations}

Integrating relevant information into ecological recommendations at multiple temporal and spatial scales occurs through a series of seasonal, weekly, and/or daily meetings that occur at key times throughout the year. The scope of discussions and recommendations become more narrowly focused with increased meeting frequency. The utilization of available tools and monitoring information allow the characterization and assessment of species-specific habitat conditions as well as the potential impact of operational decisions on indicator species. Recommendations focus on addressing ecological needs of the Everglades more than specific operational decisions, although incorporating information about the feasibility of operations and regulatory guidelines strengthen recommendations. Some specific operational recommendations can be made, such as recommending preferred volumes and rates of inflows/outflows at specific structures, but only in areas that fall within existing regulatory frameworks and guidelines that can be feasibly considered (i.e., without formally updating regulatory guidelines).

Seasonal meetings generally occur at the beginning of the dry and wet seasons, as well as one meeting during the transition between wet and dry seasons (October, January, and May). These meetings focus on assessing conditions, characterizing desired ecological outcomes for the upcoming season, and defining water management guidelines for achieving those desired outcomes. Meetings are typically fullday, in-person workshops that include species updates (monitoring and research), overviews of current, past, and expected future climate conditions, a summary of ongoing and planned operations, and short- (7-10 days) and mid/long-term climate outlook discussions to develop recommendations for achieving desired ecologic (30-90 days) al outcomes. Meeting participants include key stakeholders such as agency, university, and non-governmental organization scientists. Factors such as short- and long-term stakeholder/managing agency goals and inter-annual variability of indicator species population dynamics are also considered when making recommendations. Seasonal recommendations are based on the overall assessment of conditions (past, present, and future) and typically include the identification of priority species and areas within the system, the characterization of desired ecological outcomes for the upcoming season, and the development of seasonal targets for rates of change in water depth and hydroperiod based on current conditions as indicated by monitoring data and modeled species habitat suitability. Recommendations can also include generalized recommendations such as to retain water where storage is available (per regulatory guidelines), to avoid particular operations that can have deleterious habitat impacts (e.g., degraded water quality), and/or suggestions that foster more natural (e.g., applying a ramping approach when adjusting structure inflows/outflows). Ecological thresholds and/or targets for other species and habitats, such as alligators and tree islands, also inform recommendations to benefit the greatest number, and/or highest priority (most sensitive or imperiled) of species across the landscape. Seasonal meetings tend to have the highest number of participants because a broader range of stakeholders, (many of which are identified 
26.1.3), including non-governmental organizations, local municipalities, natural resource management agencies, and researchers from a range of organizations, are interested in providing species and habitat updates and input towards longer-term recommendations. Accounting for variability throughout the system, as well as agency-specific missions, directives, and/or priorities, recommendations are provided at multiple spatial and temporal scales as appropriate.

Once seasonal recommendations are developed, a smaller, core group of species experts and agency biologists evaluate, update, and communicate recommendations in real-time. Weekly meetings of a core group of primarily managing agency scientists develop habitat condition updates as well as any necessary updates to seasonal ecological recommendations. Weekly ecological recommendations typically include assessment of current and expected (short- and mid-term) conditions of habitat and wildlife populations, recent operations, and projected rainfall trends. Ultimately, the group identifies areas with sensitive habitats/wildlife populations (e.g., nesting wading bird colonies), and/or localized areas that could ecologically benefit from more/less water.

Weekly and/or daily coordination teleconferences typically take place during the dry season and coincide with wading bird, Snail Kite, and Cape Sable Seaside Sparrow nesting seasons. These coordination meetings partially focus on these indicator species to assess current conditions and short-term climate predictions to make targeted, short-term recommendations, often resulting in updating and refining seasonal recommendations to promote desired outcomes. The scope and focus of weekly and/or daily meetings tends to be narrower than in seasonal meetings. These meetings are often followed up with daily or semi-daily coordination meetings with agency scientists and managers during the occurrence of major events such as significant rainfall or changes in operations.

Group recommendations and updates are communicated to operations managers at the SFWMD and USACE through written reports developed by the group and presented during weekly operations meetings by agency scientists that participate in both the development of ecological recommendations and agency water management operations meetings. Routinely providing recommendations in other forums, such as regulatory Periodic Scientist Calls, which are monthly public coordination calls mandated by ESA consultation and hosted by USACE, as well as intra-agency management communication chains support coordinated recommendations across management agencies.

Available tools are currently integrated within the recommendation-making process to various degrees. Further integration of real-time population distribution and conditions would enhance the ability to understand and communicate short-term ecological needs. As additional decision support tools are developed and implemented, a combination of current conditions, past conditions, and past climate conditions over a long period can be used to determine the most likely wildlife response to water trends across the Everglades system for the upcoming season. These likely scenarios can be evaluated, and recommendations made, for individual species or a select group of species (e.g., wading birds). One highly anticipated tool currently under development is a species-forecasting tool (USGS) that considers 
habitat requirements and potential habitat suitability in the upcoming season for an entire collection of indicator species based on expected water level trends. Water trend scenarios can then be evaluated for their benefits to the greatest number or highest priority indicator species, which can help define priorities and potential outcomes. An early version of this tool is currently being tested and studied to determine the best way to integrate it into decision-making processes.

An infographic depicting information about current ecological conditions and species distributions, specifically designed for operations managers, is currently in development. This graphic is intended to provide a visual summary of recommendations and the ecological conditions that influenced them in order to more effectively communicate ecological needs and document the decision process to operations managers. An additional in-depth annual review of how recommendations influenced water operations and promoted desired ecological outcomes would allow further understanding of how ecological components are incorporated into the decision-making process and support refinement of how recommendations are made to maximize EBM effectiveness. Finally, additional benefits could be gained from the available tools and communication strategies if they were incorporated into existing and future regulatory guidance.

\section{Conclusion}

A suite of EBM activities support multi-purpose management of the Everglades ecosystem to provide ecosystem services as well as support plant and wildlife communities. With a focus on stakeholder engagement, communication, and the development/use of tools to integrate a wide range of conditions, operations, climate, and wildlife population data, the EBM framework presented here promotes consistent and effective management and restoration of the Everglades to meet a wide range of complex goals, needs, and ecological targets.

Stakeholder participation and communication is key to the effectiveness of this multiple element, decision-making EBM process in a complex socio-ecological system. Engagement by interested parties, researchers, and managing agencies enable integration of local and regional priorities to support healthy wildlife and habitats, as well as provide critical ecological services (e.g., flood control, water supply). Documenting the process and results for developing recommendations promotes communication with stakeholders and provides a record that can be used for adaptive learning.

This multi-agency/stakeholder approach to using integrative tools and real-time monitoring data for coordinating and developing comprehensive and effective water management recommendations is superior to previous approaches because this method is inclusive, transparent, comprehensive, and provides a landscape context to recommendations for individual management areas. The coordination of ecological recommendations among scientists from the various land management agencies across the landscape integrates research, monitoring, and stakeholder interests, and 
provides water managers with a more holistic and cohesive set of recommendations for supporting wildlife and habitats, even when there is not full consensus regarding ecological recommendations among the agencies due to area/agency-specific goals and objectives. A dedicated focus on stakeholder engagement facilitates the inclusion of local expertise (representing those stakeholders identified in Sect. 2.3) provided by agency biologists, who manage individual areas, with information provided by university and agency scientists that monitor regional conditions and wildlife. Stakeholder engagement allows for the incorporation of valuable insights from these and other stakeholders into the development of recommendations that integrate specific needs of individual areas with the needs of the Everglades ecosystem as a whole.

Acknowledgements We would like to thank Steve Henry, Miles Meyers, Darryl Marois, Manual Lago, and Ana I. Lillebø for valuable reviews of earlier versions of this manuscript. The views expressed in this chapter are those of the authors and do not necessarily reflect the views or policies of the U.S. Fish and Wildlife Service, U.S. Department of Interior, or the U.S. Environmental Protection Agency. Mention of trade names or commercial products does not constitute endorsement or recommendation for use.

\section{References}

Ankersen, T., \& Hamann, R. (1996). Ecosystem management and the Everglades: A legal and institutional analysis. The Journal of Land Use \& Environmental Law, 11, 473-536.

Bennetts, R. E., \& Kitchens, W. M. (1997). Population dynamics and conservation of snail kites in Florida: The importance of spatial and temporal scales. Colon Waterbird, 20(2), 324-329.

Bennetts, R. E., Collopy, M. W., \& Beissinger, S. R. (1988). Nesting ecology of snail kites in water conservation area $3 A$ (pp. 1-174). Department of Animals and Range Sciences, University of Florida, 32.

Cattau, C. E., Kitchens, W. M., Reichert, B. E., Bowling, A., Hotaling, A., Zweig, C., Olbert, J., Pias, K., \& Martin, J. (2008). Demographic, movement, and habitat studies of the endangered snail kite in response to operational plans in Water Conservation Area 3. Gainesville, FL: US Geological Survey Biological Resources, Division, Florida Cooperative Fish and Wildlife Research Unit.

Darby, P. C., Bennetts, R. E., Miller, S. I., \& Percival, H. F. (2002). Movements of Florida apple snails in relation to water levels and drying events. Wetlands, 22(3), 489-498.

Doren, R. F., Trexler, J. C., Gottlieb, A. D., \& Harwell, M. C. (2009). Ecological indicators for system-wide assessment of the greater Everglades ecosystem restoration program. Ecological Indicators, 9(6), S2-S16.

Douglas, M. S. (1947). The Everglades: River of Grass. New York: Rinehart.

Everglades National Park (ENP). (2015). Hydrologic monitoring program. Retrieved March 20, 2019, from https://www.nps.gov/ever/learn/nature/hydromon.htm.

Frederick, P. C., \& Ogden, J. C. (2001). Pulsed breeding of long-legged wading birds and the importance of infrequent severe drought conditions in the Florida Everglades. Wetlands, 21(4), 484-491.

Harwell, M. A. (1997). Ecosystem management of South Florida: Developing a shared vision of ecological and societal sustainability. Bioscience, 47(8), 499-512.

Harwell, M. C., Molleda, J. L., Jackson, C. A., \& Sharpe, L. (2020). Establishing a common framework for strategic communication in ecosystem-based management and the natural 
sciences. In T. O'Higgins, M. Lago, \& T. H. DeWitt (Eds.), Ecosystem-based management, ecosystem services and aquatic biodiversity: Theory, tools and applications (pp. 165-188). Amsterdam: Springer.

Hirsch, R. M. (1978). Risk analysis for a water-supply system - Occoquan reservoir, Fairfax and prince William counties, Virginia. Hydrological Sciences Bulletin, 23(4), 476-505.

Kushlan, J. A. (1979). Design and management of continental wildlife reserves: Lessons from the Everglades. Biological Conservation, 15(4), 281-290.

Kushlan, J. A. (1987). External threats and internal management: The hydrologic regulation of the Everglades, Florida, USA. Environmental Management, 11(1), 109-119.

Light, S. S., \& Dineen, J. W. (1994). Water control in the Everglades: A historical perspective. In S. M. Davis \& J. C. Ogden (Eds.), Everglades: The ecosystem and its restoration (pp. 47-84). Boca Raton, FL: St. Lucie Press.

Long, R. D., Charles, A., \& Stephenson, R. L. (2015). Key principles of marine ecosystem-based management. Marine Policy, 57, 53-60.

LoSchiavo, A., Best, R., Burns, R., Gray, S., Harwell, M., Hines, E., McLean, A., St. Clair, T., Traxler, S., \& Vearil, J. (2013). Lessons learned from the first decade of adaptive management in comprehensive Everglades restoration. Ecology and Society, 18(4), 70.

Mattheiß, V., Strosser, P., Krautkraemer, A., Charbonnier, C., McDonald, H., Röschel, L., Hoffmann, H., Lago, M., Delacámara, G., Gómez, C. M., Piet, G., Schuwirth, N., Kuemmerlen, M., \& Reichert, P. (2018). Evaluation of ecosystem-based management responses in case studies: AQUACROSS Deliverable 8.2. European Union's Horizon 2020 Framework Programme for Research and Innovation Grant Agreement No. 642317. Retrieved October 20, 2019, from www.aquacross.eu.

McVoy, C., Said, W. P., Obeysekera, J., VanArman, J. A., \& Dreschel, T. W. (2011). Landscapes and hydrology of the pre-drainage Everglades (pp. 1-31). Gainesville, FL: University Press of Florida.

National Academies of Sciences, Engineering, and Medicine. (2018). Progress Toward Restoring the Everglades: The Seventh Biennial Review-2018. Washington, DC: The National Academies Press.

National Research Council. (2010). Progress toward restoring the Everglades: The Third Biennial Review - 2010. Washington, DC: The National Academies Press.

Ogden, J. C. (1994). A comparison of wading bird nesting colony dynamics (1931-1946 and 1974-1989) as an indication of ecosystem conditions in the Southern Everglades. In S. M. Davis \& J. C. Ogden (Eds.), Everglades: The ecosystem and its restoration (pp. 533-570). Boca Raton, FL: St. Lucie Press.

Ogden, J. C. (2005). Everglades ridge and slough conceptual ecological model. Wetlands, 25(4), $810-820$.

Piet, G., Delacamara, G., Lago, M., Rouillard, J., Martin, R., \& van Duinen, R. (2017). Making ecosystem-based management operational. Deliverable 8.1, European Union's Horizon 2020 Framework Programme for Research and Innovation grant agreement No. 642317.

RECOVER. (2009). Monitoring and Assessment Plan (MAP). Restoration Coordination and Verification, c/o U.S. Army Corps of Engineers, Jacksonville, Florida, USA, and South Florida Water Management District, West Palm Beach, Florida, USA. Retrieved March 20, 2019, from http://www.evergladesplan.org/pm/recover/recover_map.aspx.

Schlesinger, W. H. (2010). Translational ecology. Science, 329(5992), 609.

Snyder, G. H., \& Davidson, J. M. (1994). Chapter 5. Everglades agriculture: Past, present, and future. In S. M. Davis \& J. C. Ogden (Eds.), Everglades: The ecosystem and its restoration. Boca Raton, FL: St. Lucie Press.

South Florida Water Management District (SFWMD). (2016). Facility and infrastructure location index map. West Palm Beach, FL. Retrieved March 20, 2019, from https://www.sfwmd.gov/ sites/default/files/documents/facility_map_overview.pdf.

South Florida Water Management District (SFWMD). (2019). Operational planning. Retrieved March 20, 2019, from https://www.sfwmd.gov/science-data/operational-planning. 
U.S. Army Corps of Engineers (USACE). (2019). Water management. Retrieved March 20, 2019, from https://www.saj.usace.army.mil/Missions/Civil-Works/Water-Management/.

US Department of the Interior. (1994). The Everglades, Coastal Louisiana, Galveston Bay, Puerto Rico, California's Central Valley, Western Riparian Areas, Southeastern and Western Alaska, The Delmarva Peninsula, North Carolina, Northeastern New Jersey, Michigan, and Nebraska, p. 123, vol. II of The Impact of Federal Programs on Wetlands. A Report to Congress by the Secretary of the Interior. Washington, DC: Department of the Interior.

U.S. Fish and Wildlife Service (USFWS). (1999). South Florida multi-species recovery plan. U.S. Fish \& Wildlife Service, Atlanta, Georgia. Retrieved March 20, 2019, from https://www. fws.gov/verobeach/listedspeciesmsrp.html.

U.S. Fish and Wildlife Service (USFWS). (2010). U.S. fish and wildlife service biological opinion for Everglades Restoration Transition Plan, Phase 1. Vero Beach, FL.

U.S. Fish and Wildlife Service (USFWS). (2014). Central Everglades Planning Project biological opinion. Vero Beach, FL.

U.S. Fish and Wildlife Service (USFWS). (2016). Biological opinion for the Everglades Restoration Transition Plan-2016. Vero Beach, FL. Retrieved March 20, 2019, from https://www.fws. gov/verobeach/NewsReleasesPDFs/20160722ERTPJeopardyBO_FAQs.pdf.

U.S. Geological Survey (USGS). (2009). Everglades Depth Estimation Network (EDEN) Applications: Tools to view, extract, plot, and manipulate EDEN data. Retrieved March 20, 2019, from https://pubs.usgs.gov/fs/2009/3052/pdf/fs2009-3052_spread.pdf.

U.S. Geological Survey (USGS). (2013). Water Conservation Areas (WCAs). Retrieved March 20, 2019, from https://archive.usgs.gov/archive/sites/sofia.usgs.gov/virtual_tour/controlling/ wca.html.

USACE and SFWMD. (1999). Central and Southern Florida Project Comprehensive Review Study: Final Integrated Feasibility Report and Programmatic Environmental Impact Statement. U.S. Army Corps of Engineers, Jacksonville, Florida, USA, and South Florida Water Management District, West Palm Beach, Florida, USA. Retrieved March 20, 2019, from http://www. evergladesplan.org/docs/comp_plan_apr99/summary.pdf.

Walker, W. W., Jr. (1999). Long-term water quality trends in the Everglades. In K. R. Reddy, G. A. O'Connor, \& C. L. Schelske (Eds.), Phosphorus biogeochemistry in sub-tropical ecosystems: Florida as a case example. Boca Raton, FL: CRC/Lewis Publishers.

Open Access This chapter is licensed under the terms of the Creative Commons Attribution 4.0 International License (http://creativecommons.org/licenses/by/4.0/), which permits use, sharing, adaptation, distribution and reproduction in any medium or format, as long as you give appropriate credit to the original author(s) and the source, provide a link to the Creative Commons licence and indicate if changes were made.

The images or other third party material in this chapter are included in the chapter's Creative Commons licence, unless indicated otherwise in a credit line to the material. If material is not included in the chapter's Creative Commons licence and your intended use is not permitted by statutory regulation or exceeds the permitted use, you will need to obtain permission directly from the copyright holder.

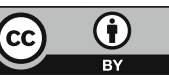

